Original Article

\title{
PHYTOCHEMICAL INVESTIGATION, GC-MS PROFILE AND ANTIMICROBIAL ACTIVITY OF A MEDICINAL PLANT RUTA GRAVEOLENS L. FROM ETHIOPIA
}

\author{
HENOK GULILAT AZALEWORK ${ }^{1}$, SAHABJADA ${ }^{2}$, ASIF JAFRI ${ }^{2}$, MD ARSHAD ${ }^{2}$, TABARAK MALIK ${ }^{*}$ \\ ${ }^{1}$ Department of Biomedical Sciences, College of Health Sciences, Jimma University, Jimma, 378, Ethiopia, ${ }^{2}$ Molecular Endocrinology \\ Laboratory, Department of Zoology, University of Lucknow, Lucknow 226007, India \\ Email: tabarak.malik@ju.edu.et
}

Received: 27 Dec 2016 Revised and Accepted: 20 Apr 2017

\section{ABSTRACT}

Objective: This study was designed to screen the phytochemicals present in various solvents extracts of Ruta graveolens (Rue) and furthermore to investigate their antimicrobial activity.

Methods: The leaves, stems and seeds of Rue were extracted using four different solvents viz. ethanolic, methanolic, chloroform, and aqueous of varying polarity. The phytochemical screening was carried out qualitatively and Gas Chromatography-Mass Spectroscopy (GC-MS) analysis was performed to identify major phytoconstituents present in the methanolic leaf extract. The antimicrobial effect of extracts was evaluated against six microbial strains namely Bacillus subtillis, Escherichia coli, Proteus vulgaris, Candida albicans, Candida tropicalis and Micrococcus luteus with disc diffusion method.

Results: Phytochemical analysis revealed the presence of various secondary metabolites such as flavonoids, alkaloids, terpenoids, saponins and carotenoid. The methanolic leaf extract showed the presence of both tannin and phenolic contents in the higher amount, whereas aqueous extract displayed in the least amount. GC-MS analysis of methanolic leaf extract revealed the presence of approximately 26 phytochemical constituents. The antimicrobial assay revealed that $B$. subtilis showed a high zone of inhibition $(20 \mathrm{~mm})$ at $200 \mathrm{mg} / \mathrm{ml}$ of methanolic extract. However, $E$. coli and $C$. tropicalis did not show any zone of inhibition against each solvent extract.

Conclusion: In conclusion, secondary metabolites present in the extracts have biological activities which warrant further to evaluate in vivo pharmacological studies.

Keywords: Ruta graveolens, Anti-microbial, Phytochemicals, GC-MS analysis

(C) 2017 The Authors. Published by Innovare Academic Sciences Pvt Ltd. This is an open access article under the CC BY license (http://creativecommons.org/licenses/by/4.0/) DOI: http://dx.doi.org/10.22159/ijpps.2017v9i6.16812

\section{INTRODUCTION}

Medicinal plants and their products have been imparted valuable role for human health for thousands of years. In regards to medicinal valuable plants; nature provides us a reservoir of millions of natural products and also their derivatives which contain antioxidant, antimicrobial, anti-inflammatory, anti-tumor, anti-mutagenic, anticarcinogenic and anti-diabetic potentials [1]. According to recent data from World Health Organization (WHO), 70-80 \% of developing countries populations are using traditional plant products as an alternative or complementary medicine [2]. Herbal medicines are relatively safe for human use, thus plant-based antimicrobials medicines have immeasurable remedial potential that can serve the purpose with lesser side effect and also work against pathogens, those are multidrug resistant.

In the present study, the test plant Ruta graveolens (Rue) was explored for it's bioactive, pharmacological and nutraceutical values. Rue is an odoriferous medicinal herb belonging to the family Rutaceae. It is a perennial herb well-known for its anti-leucodermal, anti-inflammatory and anti-cancer properties and is common name is Rue. Rue is native to Europe and also Mediterranean-Balkan Peninsula region and it was brought to Mexico and Tropics of America by Spanish [3]. Rue is also widely distributed in West Indies, Mexico, East Africa (Ethiopia), central South America and India $[4,5]$. In Ethiopia, the leaves and berries of Rue are used in special cuisine, which was made by adding a characteristic Ethiopian spice mixture known as berbere. Rue oil is also used as a flavoring in foods and beverages and as fragment ingredient in manufacturing soaps and cosmetics.

Not only a delicacy but Rue is also having the wide range of medicinal usages; common uses in fertility regulation, menstrual cramps, earache, headache, nosebleed, strengthens eyesight and helps prevent fatigue and sore in eyes and insect repellent. Moreover, Rue is also known to be used as diaphoretic, emetic, digestive stimulation, treatment of measles, scarlet fever, and heart problems, a remedy for epilepsy, vermifuge, diaphoretic, treatment of ulcer and gum problems [6, 7]. Brushed leaves are placed on a tooth or in the ear for pain relief $[8,9]$. Rue extract is also believed to improve blood circulation, regulate blood pressure and help to prevent varicose veins and atherosclerosis. Rue oil is a commonly used homeopathic medicine as a rubefacient, in certain dermatoses as eczemas and psoriasis, and as an antiviral agent [8].

Various active ingredients present in Rue extract, which imparts its medicinal values. Rue contains a di-glycoside of quercetin known as rutin, a flavonoid, which is an active compound to scavenge nitric oxide [10]. Rue extract was also reported to scavenge hydroxyl radicals and inhibit lipid peroxidation at low concentrations [8]. Two acridone alkaloids namely arborinine and evoxanthine and furanoacridones, isolated from Rue plant have shown potent anticancer activity [11]. However, research is remaining to analyze phytoconstituents and their biological investigation.

Based on the previous reports, this study was designed to evaluate the phytochemicals present in the various solvent extract of Rue plant and subsequently, identified a variety of phytocomponents in the methanolic extract of Rue by using Gas Chromatography-Mass Spectroscopy (GC-MS). In addition, the antimicrobial activity of Rue extract was also investigated.

\section{METHODS AND MATERIALS}

Chemicals and reagents

Chloroform, DMSO, sulphuric acid $\left(\mathrm{H}_{2} \mathrm{SO}_{4}\right)$, diluted ammonia, ferric chloride $\left(\mathrm{FeCl}_{3}\right)$, hydrogen chloride $(\mathrm{HCl})$, deionised distilled water, Folin-Ciocalteau reagent, Draggendorff's reagent, sodium carbonate 
and gallic acid were used for phytochemical screening. MuellerHinton broth and agar media were used for the antibacterial assay. The entire reagents used were of Sigma and Himedia, India.

\section{Instruments}

Grinder, water bath, glassware (conical flasks, beakers, test tubes, Petri plates), micropipettes, gel puncher, digital balance, incubator, laminar flow hood, hot air oven, spectrophotometer, gas chromatography-mass spectrometry, refrigerator, autoclave and microwave oven.

\section{Microorganism used}

The organisms used are Candida albicans (MTCC 183), Candida tropicalis (MTCC 184), Escherichia coli (MTCC 443), Proteus vulgaris (MTCC 426), Micrococcus luteus (MTCC 1538) and Bacillus subtillis (MTCC 441). These were preserved at CSIR-Central Leather Research Institute, Adyar, Chennai (India).

\section{Plant material}

The experimental plant Rue was collected from a local garden of Addis Ababa, Ethiopia in the month of December and January. Rue plant is harvested in early summer shortly before flowering begins. Plant samples were identified as Rue by the taxonomist at School of Biotechnology, Lovely Professional University, India. A reference specimen (voucher No.) of this plant is LPU/PHAR/HRB/13/06. The whole plant and the seed were washed thoroughly with sterile distilled water in order to remove dirt and dust present on the surface. The plant and seeds were then dried in shade for $15 \mathrm{~d}$. The leaves, stems and the seeds were separately made into a fine powder in the grinder, which passed through 40-micron mesh. The powder was kept in airtight amber colour bottle till used.

\section{Plant extract preparation}

The powdered samples were mixed with solvents like methanol, acetone, chloroform and distilled water individually in 1:20 ratio. In this method, $30 \mathrm{~g}$ of the sample powder was percolated with $600 \mathrm{ml}$ of solvent in a screw capped conical flask separately and the entire flasks were placed in a shaker at $100 \mathrm{rpm}$ at room temperature for $24 \mathrm{~h}$. After $24 \mathrm{~h}$ of shaking, all the extracts were filtered by busing a clean muslin cloth and then re-filtered by Whatman no. 1 filter paper. The filtrate was then collected in a fresh beaker and concentrated by evaporating the solvents in a water bath at 35-40 ${ }^{\circ} \mathrm{C}$. The extracts were labeled accordingly and were kept in a refrigerator at $4{ }^{\circ} \mathrm{C}$ until use [12].

\section{Phytochemical screening qualitative analysis}

The preliminary phytochemicals (carbohydrates, fatty acids, proteins, saponins, tannins, flavonoids, alkaloids, terpenoids, cardiac glycosides, carotenoids, polyphenol, and amino acids) screening of various solvents extracts were carried out using standard procedure to identify the various phytoconstituents $[13,14]$.

\section{Quantitative estimation of tannins}

The quantitative determination of tannin in Rue sample was performed as per protocol [15]. Briefly, $500 \mathrm{mg}$ of the dried extract was dissolved in $50 \mathrm{ml}$ of distilled water in a screw caped conical flask and allowed to shake for $1 \mathrm{~h}$. Approximately $5 \mathrm{ml}$ of filtrate was mixed with $2 \mathrm{ml}$ of $0.1 \mathrm{M} \mathrm{FeCl}_{3}$ in $0.1 \mathrm{~N} \mathrm{HCl}$ and $0.008 \mathrm{M}$ potassium ferrocyanide. The absorbance was measured at $120 \mathrm{~nm}$ within 10 min by UV-visible spectrophotometer. All the experiments were carried out in triplicate.

\section{Quantitative determination of total phenolic content}

The total phenols content in Rue was determined by the spectrophotometric method as per protocol with minor modification [16]. The dried extract was boiled with $50 \mathrm{ml}$ of ether for the extraction of the phenolic component for $15 \mathrm{~min}$. A $5 \mathrm{ml}$ of the extract was mixed with $10 \mathrm{ml}$ of distilled water, $2 \mathrm{ml}$ of ammonium hydroxide solution and $5 \mathrm{ml}$ of concentrated amyl alcohol into a 50 $\mathrm{ml}$ flask and incubated at room temperature for $30 \mathrm{~min}$ for color development. Absorbance was measured at $505 \mathrm{~nm}$ by a spectrophotometer. All the experiments were performed in triplicate and assay of the total phenolic content was expressed in $\mathrm{mg}$ gallic acid equivalent per $\mathrm{g}$ of the extract by comparing with gallic acid as standard.

\section{Gas chromatography-mass spectrometry (GC-MS) analysis}

In this method, $5 \mathrm{~g}$ of powdered Rue were soaked in methanol overnight and then filtered through a Whatman no. 41 filter paper. The filtrate was then concentrated by bubbling nitrogen gas into the solution. GC-MS analysis of the extract was performed using a Perkin Elmer GC Claurus 500 system and Gas Chromatograph interfaced to a Mass Spectrometer equipped with an Elite-5MS fused silica capillary column. For GC-MS detection, an electron ionization system with ionization energy of $70 \mathrm{eV}$ was used. Helium gas (99.99\%) was used as the carrier gas at a constant flow rate of $1 \mathrm{ml} / \mathrm{min}$ and an injection volume of $3 \mathrm{ml}$ was employed (split ratio of 10:1). The injector temperature was at $250^{\circ} \mathrm{C}$ and ion source temperature was adjusted at $280^{\circ} \mathrm{C}$. The oven temperature was programmed from $110^{\circ} \mathrm{C}$ (isothermal for $2 \mathrm{~min}$ ) with an increase of $10^{\circ} \mathrm{C} / \mathrm{min}$ to 200 ${ }^{\circ} \mathrm{C}$, then $5{ }^{\circ} \mathrm{C} / \mathrm{min}$ to $280^{\circ} \mathrm{C}$ ending with a $9 \mathrm{~min}$ isothermal at $280^{\circ} \mathrm{C}$. Mass spectra were taken at $70 \mathrm{eV}$, a scan interval of $0.5 \mathrm{sec}$ and fragments from 45 to $450 \mathrm{Da}$. The relative percentage amount of each component was calculated by comparing its average peak area to the total areas. Software adapted to handle mass spectra and chromatograms was a TurboMass Version 5.2.0. Interpretation on mass-spectrum GC-MS was conducted using the database of National institute Standard and Technology (NIST) having more 62,000 patterns. The spectrum of the unknown components was compared with the spectrum of known components stored in the NIST library and the molecular weight and structure of the compound.

\section{Antimicrobial susceptibility test}

Screening for antimicrobial activity of different solvent extracts of Rue was carried out by commonly known disc diffusion method accordingly with minor modification [17]. The sterile empty disc was prepared from Whatman no.1 filter paper of $6 \mathrm{~mm}$ in diameter. In two screw cap tube, $100 \mathrm{mg}$ and $200 \mathrm{mg}$ of each dried extract were dissolved in phosphate buffer saline (PBS). A $10 \mu$ of the respective solvent of Rue extract was added to the discs $(1 \mathrm{mg} / \mathrm{disc}$ and 2 $\mathrm{mg} /$ disc respectively) individually and aseptically. Discs were then allowed to dry in laminar air flow hood at room temperature, in order to maintain sterile condition. After drying, these discs were used for screening the antibacterial activity. In disc diffusion analysis, the stock cultures of bacteria were revived by inoculating in broth media and grown at $37^{\circ} \mathrm{C}$ for $18 \mathrm{~h}$ in an incubator. Agar plates of the Muller Hilton's Agar media were prepared. Each plate was then inoculated by swabbing with bacterial suspension or with $18 \mathrm{~h}$ fresh culture (105106 colony forming unit "CFU" $/ \mathrm{ml}$ ), which was swabbed evenly on the surface of solid agar media by the help of sterilized cotton swab. After 20 min, previously prepared discs of Whatman no. 1 paper with different extracts concentration were placed on the surface of agar medium. Standard antibiotic discs were used as a positive control to compare the antibacterial activity. All the plates were incubated at 37 ${ }^{\circ} \mathrm{C}$ for $24 \mathrm{~h}$ and then the diameter of the zone of inhibition was measured in $\mathrm{mm}$. All types of equipment and media were proper labeled and sterilized before performing the experiments.

\section{Statistical analysis}

The phytochemicals and antimicrobial tests were conducted in triplicate and the results were expressed as mean \pm standard deviation (SD). Analysis of variance (ANOVA), Tukey's HSD, and least significant difference (LSD) tests were applied using Statistical Package for the Social Sciences (SPSS version 19.0, IBM Corp., Armonk, NY, USA) for comparisons of variance and means, and differences were considered significant at $p \leq 0.05$.

\section{RESULTS AND DISCUSSION}

\section{Phytochemicals containing tannins and phenolic contents}

Table 1 represents the qualitative analysis of phytochemicals present in the various solvent extract of Rue. The qualitative analysis of methanolic Rue extract showed the presence of more phytochemicals as compared with other solvent extracts of the leaf, stem and seed samples. The methanolic extract of the leaf also 
showed the presence of high amount of tannin. However, seed extracts in all four solvent showed a very low amount of tannin (table 2). The previous study also supported the presence of different phytochemicals viz. alkaloids, flavonoids, terpenoids, saponins and polyphenols present in different parts of plant extracts of Ruta plants [18-20].

Table 1: Qualitative analysis of phytochemicals present in Rue with various solvent extract

\begin{tabular}{|c|c|c|c|c|c|c|c|c|c|c|c|c|c|c|c|c|c|c|c|c|c|c|c|c|}
\hline \multicolumn{25}{|c|}{ Phytochemical analysis of the plant using ethanolic extract } \\
\hline \multirow{2}{*}{$\begin{array}{l}\text { Phytochemica } \\
\text { l constituents } \\
\text { Leaf extract }\end{array}$} & \multicolumn{2}{|c|}{$\begin{array}{c}\text { Carboh- } \\
\text { ydrate }\end{array}$} & \multicolumn{2}{|c|}{$\begin{array}{l}\text { Fatty } \\
\text { acid }\end{array}$} & \multicolumn{2}{|c|}{$\begin{array}{l}\text { Protei } \\
\text { n }\end{array}$} & \multicolumn{2}{|c|}{$\begin{array}{l}\text { Saponi } \\
\text { ns }\end{array}$} & \multicolumn{2}{|c|}{$\begin{array}{l}\text { Tannin } \\
\text { s }\end{array}$} & \multicolumn{2}{|c|}{$\begin{array}{l}\text { Flava } \\
\text { noids }\end{array}$} & \multicolumn{2}{|c|}{$\begin{array}{l}\text { Alkal } \\
\text { oids }\end{array}$} & \multicolumn{2}{|c|}{$\begin{array}{l}\text { Terpe } \\
\text { noids }\end{array}$} & \multicolumn{2}{|c|}{$\begin{array}{l}\text { Glyco } \\
\text { sides }\end{array}$} & \multicolumn{2}{|c|}{$\begin{array}{l}\text { Caroti } \\
\text { noide }\end{array}$} & \multicolumn{2}{|c|}{$\begin{array}{l}\text { Polyphenol } \\
\text { S }\end{array}$} & \multicolumn{2}{|c|}{$\begin{array}{l}\text { Amin } \\
\text { o acid }\end{array}$} \\
\hline & - & - & - & - & - & - & + & + & + & + & + & + & + & + & + & + & + & + & - & - & - & - & + & + \\
\hline Seed extract & - & - & - & - & - & - & + & + & + & + & + & + & + & + & + & + & + & + & - & - & - & - & + & + \\
\hline \multicolumn{25}{|c|}{ Phytochemical analysis of the plant using methanolic extract } \\
\hline Leaf extract & - & - & - & - & - & - & + & + & + & + & + & + & + & + & + & + & + & + & + & + & - & - & + & + \\
\hline Stem extract & - & - & - & - & - & - & + & + & + & + & + & + & + & + & + & + & + & + & + & + & + & + & + & + \\
\hline Seed extract & - & - & - & - & - & - & + & + & + & + & + & + & + & + & + & + & + & + & + & + & - & - & + & + \\
\hline \multicolumn{25}{|c|}{ Phytochemical analysis of the plant using chloroform extract } \\
\hline Leaf extract & - & - & - & - & - & - & + & + & + & + & + & + & + & + & + & + & + & + & - & - & - & - & + & + \\
\hline Stem extract & - & - & - & - & - & - & + & + & + & + & + & + & + & + & + & + & + & + & - & - & + & + & + & + \\
\hline Seed extract & - & - & - & - & - & - & + & + & + & + & + & & + & + & + & + & + & + & - & - & - & - & + & + \\
\hline \multicolumn{25}{|c|}{ Phytochemical analysis of the plant using aqueous extract } \\
\hline Leaf extract & - & - & - & - & - & - & + & + & + & + & + & + & + & + & + & + & - & - & - & - & - & - & + & + \\
\hline Stem extract & - & - & - & - & - & - & + & + & - & - & + & + & + & + & + & + & - & - & + & + & + & + & + & + \\
\hline Seed extract & - & - & - & - & - & - & + & + & + & + & + & + & + & + & + & + & - & - & - & - & - & - & + & + \\
\hline
\end{tabular}

'+'-Present, '-'-Absent

Table 2: Quantitative estimation of phenols and tannins in various solvent extracts of rue

\begin{tabular}{llll}
\hline Tests & Solvent for extraction & Plant part & \\
\cline { 2 - 4 } & & Leaf (\%) & Stem (\%) \\
\hline Estimation of Tannins & Ethanolic extract & $15.15 \pm 0.30$ & $15.25 \pm 0.41$ \\
& Methanolic extract & $18.25 \pm 0.11$ & $15.15 \pm 0.21$ \\
& Chloroform extract & $3.10 \pm 0.10$ & $2.25 \pm 0.32$ \\
& Aqueous extract & $1.04 \pm 0.20$ & $4.25 \pm 0.51$ \\
Estimation of Total Phenolic content & Ethanolic extract & $15.62 \pm 0.01$ & $1.25 \pm 0.11$ \\
& Methanolic extract & $16.25 \pm 0.16$ & $12.25 \pm 0.15$ \\
& Chloroform extract & $15.28 \pm 0.12$ & $12.12 \pm 0.12$ \\
& Aqueous extract & $10.05 \pm 0.14$ & $15.25 \pm 0.08$ \\
& & & $9.24 \pm 0.22$ \\
\hline
\end{tabular}

‘ \pm '-Standard Deviation

\section{Analysis of GC-MS profile}

GC-MS analysis is an interesting tool to evaluate a number of active bio components used in cosmetic, pharmaceutical and food industry [21]. In the present study, we characterized the chemical profile of Rue using GC-MS. Fig. 1 represents the gas chromatogram showing the relative concentrations of various compounds eluted as a function of retention time. The height of peak indicates the relative concentrations of the components present in the plant. Mass spectrometer analyzes the compounds eluted at different times to identify the nature and structure of the compounds. The large compound fragments into small compounds giving rise to the appearance of peaks at different $\mathrm{m} / \mathrm{z}$ ratio. These mass spectra are a fingerprint of that compound which can be identified from the data library. As per previous literature survey, this is the first report to analyze the chemical constituents of Rue by GC-MS. Table 3 represents the complex chemical composition present in Rue extract. Some of the GC-MS peaks remained unidentified because of lack of authentic samples and library data of corresponding compounds.

The methanolic extract of Rue has shown about 26 active phytochemicals which contribute to the pharmacological activity of plant. The major constituents were namely Cyclohexene, 3,4diethenyl-3-methyl (peak area.21\%), Acetic acid, dec-2-yl ester (peak area $2.08 \%$ ), 2-Undecanone (peak area $0.58 \%$ ), Acetoxytetradecane (peak area $1.21 \%), 2(4 \mathrm{H})$-Benzofuranone, 5,6,7,7a-tetrahydro-4,4,7a-trimethyl-, (R) (peak area $0.60 \%$ ), Methoxybenzylamine, $\mathrm{N}, \mathrm{N}$-diethyl- $\alpha$-methyl (peak area $0.65 \%$ ), 1,4-Naphthalenedione, 2-hydroxy-3-methyl (peak area $0.85 \%$ ),
1,3-Benzodioxole, 5-(2,2-dimethylethyl) (peak area $0.61 \%$ ), 4Methoxy-benzoic acid cyclopentylidene-hydrazide,(peak area 0.49 \%), Isopsoralen,(1.34), Ficusin (peak area $0.91 \%$ ), 3-Acetamido-4hydroxy- $2(1 \mathrm{H})$-quinolinone, (peak area $0.25 \%$ ), 4-Methyl-2(phenylacetayl) phenol, (peak area $0.74 \%$ ); 7H-Furo(3,2-g) (1) benzopyran-7one, 4-methoxy, (peak area $10 \%)$, 7H-Furo(3,2-g) (1) benzopyran-7one, 4-methoxy phytol, (peak area $1.38 \%$ ), 4Butoxy-2-hydroxybenzonitrile, (peak area $0.17 \%$ ); pDimethylaminobenzylidene p-anisidine (peak area $7.73 \%$ ), $10 \mathrm{H}$ Phenothiazine, 1-methoxy, (peak area $1.66 \%$ ), 6,8-Dimethyl-3carbotheoxyquinoline, (peak area $3.33 \%$ ),2,2-Dihexylmalonic acid, diethyl ester; (peak area $0.25 \%$ ), Imindazo (2,1-b) thiazole,6phenyl, (peak area $0.29 \%$ ), Furo[2,3-b]quinoline, 4,6,7-trimethoxy(peak area7.05 \%), 2(1H)-Phenanthrenone, 3,4,4a,9,10,10ahexahydro-6-methoxy-1,1,4a-trimethyl-7-(1-methylethyl)-

(4aStrans,(53.47); 6-Aza estera-1,3,5(10),6,8-pentaen-1,7-one,3methoxy (peak area $0.55 \%), 9(10 \mathrm{H})$-Acridinone, 1-hydroxy-2,3dimethoxy-10-methyl (peak area $1.84 \%$ ) and Vitamin E (peak area $1.76 \%)$. A previous study has reported the presence of several flavonoids, alkaloids, ketone and phenolic comounds in leaf, stem and fruit parts of Rue extract [22].

Due the presence of various phytocomponents in the extract, rue plant has the potential application in various pharmaceutical industries. Alkaloids are well known for their potential and diverse pharmacological activities including analgesics, antimalarial and anti-hypertensive. Flavonoids are renowned for anti-oxidant properties including anti-cancer and antiinflammation [23]. Polyphenols are liable for antibiotic against microbial agents [24]. 


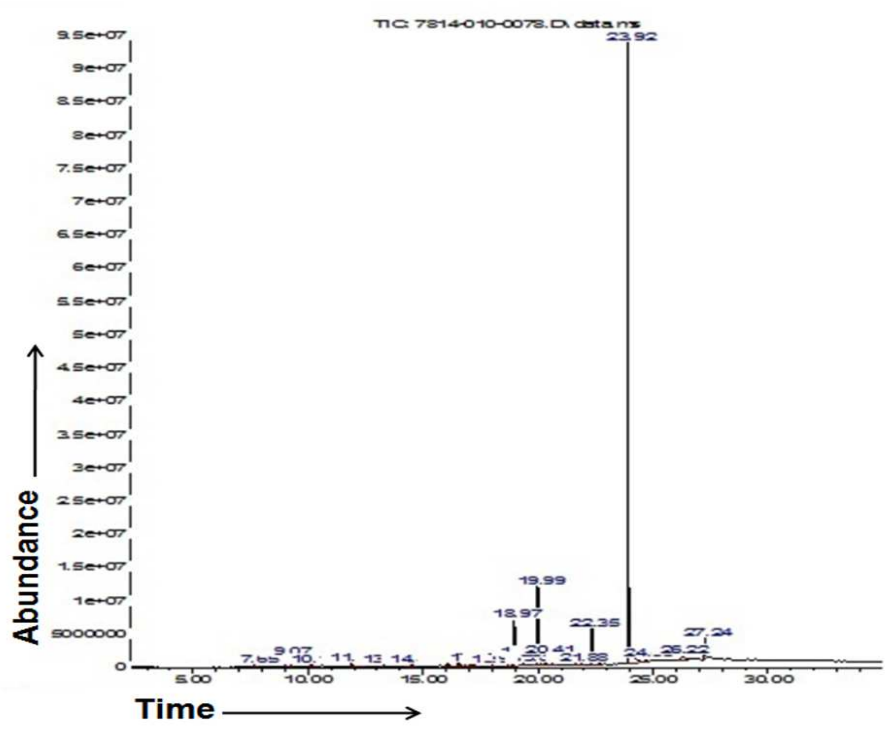

Fig. 1: Gas chromatography-mass spectroscopy chromatogram of rue plant

Table 3: Phytocomponents identified in the methanolic extract of Rue by GC-MS

\begin{tabular}{|c|c|c|c|c|c|}
\hline $\begin{array}{l}\text { S. } \\
\text { No. }\end{array}$ & $\begin{array}{l}\text { Retention } \\
\text { time }\end{array}$ & Name of the compounds & $\begin{array}{l}\text { Molecular } \\
\text { formula }\end{array}$ & Mol.Wt. & Area\% \\
\hline 1. & 7.646 & Cyclohexene, 3,4-diethenyl-3-methyl & $\mathrm{C}_{11} \mathrm{H}_{16}$ & 148 & .21 \\
\hline 2. & 9.069 & Acetic acid, dec-2-yl ester & $\mathrm{C}_{12} \mathrm{H}_{24} \mathrm{O}_{2}$ & 200 & 2.08 \\
\hline 3. & 10.173 & 2-Undecanone & $\mathrm{C}_{11} \mathrm{H}_{22} \mathrm{O}$ & 170 & 0.58 \\
\hline 4. & 11.901 & -Acetoxytetradecane & $\mathrm{C}_{16} \mathrm{H}_{32} \mathrm{O}_{2}$ & 256 & 1.21 \\
\hline 5. & 13.281 & : 2(4H)-Benzofuranone, 5,6,7,7a-tetrahydro-4,4,7a-trimethyl-, (R)- & $\mathrm{C}_{11} \mathrm{H}_{16} \mathrm{O}_{2}$ & 180 & 0.60 \\
\hline 6. & 14.486 & -Methoxybenzylamine, N,N-diethyl- $\alpha$-methyl & $\mathrm{C}_{13} \mathrm{H}_{21} \mathrm{NO}$ & 207 & 0.65 \\
\hline 7. & 16.055 & 1,4-Naphthalenedione, 2-hydroxy-3-methyl- & $\mathrm{C}_{11} \mathrm{H}_{8} \mathrm{O}_{3}$ & 188 & 0.85 \\
\hline 8. & 16.505 & 1,3-Benzodioxole, 5-(2,2-dimethylethyl)- & & 178 & 0.61 \\
\hline 9. & 16.592 & 4-Methoxy-benzoic acid cyclopentylidene-hydrazide & $\mathrm{C}_{11} \mathrm{H}_{14} \mathrm{O}_{2}$ & 207 & 0.49 \\
\hline 10. & 16.883 & Isopsoralen & $\mathrm{C}_{13} \mathrm{HN}_{2} \mathrm{O}_{3}$ & 186 & 1.34 \\
\hline 11. & 17.042 & Ficusin & $\mathrm{C}_{11} \mathrm{H}_{6} \mathrm{O}_{3}$ & 186 & 0.91 \\
\hline 12. & 18.015 & 3-Acetamido-4-hydroxy-2(1H)-quinolinone & $\mathrm{C}_{11} \mathrm{H}_{6} \mathrm{O}_{3}$ & 222 & 0.25 \\
\hline 13. & 18.727 & 4-Methyl-2-(phenylacetayl)phenol & $\mathrm{C}_{14} \mathrm{H}_{6} \mathrm{O}_{3}$ & 192 & 0.74 \\
\hline 14. & 18.974 & 7H-Furo(3,2-g)(1)benzopyran-7one, 4-methoxy & $\mathrm{C}_{11} \mathrm{H}_{16} \mathrm{~N}_{2} \mathrm{O}$ & 216 & 10 \\
\hline 15. & 19.293 & 7H-Furo(3,2-g)(1)benzopyran-7one, 4-methoxy phytol & $\mathrm{C}_{11} \mathrm{H}_{14} \mathrm{O}_{2}$ & 210 & 1.38 \\
\hline 16. & 19.816 & 4-Butoxy-2-hydroxybenzonitrile & $\mathrm{C}_{14} \mathrm{H}_{12} \mathrm{NO}$ & 92 & 0.17 \\
\hline 17. & 19.991 & p-Dimethylaminobenzylidene p-anisidine & $\mathrm{C}_{4} \mathrm{H}_{14} \mathrm{NO}$ & 254 & 7.73 \\
\hline 18. & 20.179 & 10H-Phenothiazine, 1-methoxy & $\mathrm{C}_{16} \mathrm{H}_{18} \mathrm{~N}_{2} \mathrm{O}$ & 303 & 1.66 \\
\hline 19. & 20.412 & 6,8-Dimethyl-3-carbotheoxyquinoline & $\mathrm{C}_{16} \mathrm{H}_{22} \mathrm{NH}_{3}$ & 161 & 3.33 \\
\hline 20. & 21.632 & 2,2-Dihexylmalonic acid, diethyl ester & $\mathrm{C}_{9} \mathrm{H}_{11} \mathrm{~N}_{3}$ & 251 & 0.25 \\
\hline 21. & 21.879 & Imindazo(2,1-b)thiazole,6-phenyl & $\mathrm{C}_{18} \mathrm{H}_{18} \mathrm{NH}_{3}$ & 179 & 0.29 \\
\hline 22. & 22.343 & Furo[2,3-b]quinoline, 4,6,7-trimethoxy- & $\mathrm{C}_{11} \mathrm{H}_{3} \mathrm{~N}_{2} \mathrm{O}$ & 259 & 7.05 \\
\hline 23. & 23.912 & $\begin{array}{l}\text { 2(1H)-Phenanthrenone, 3,4,4a,9,10,10a-hexahydro-6-methoxy-1,1,4a-trimethyl- } \\
\text { 7-(1-methylethyl)-(4aStrans }\end{array}$ & $\mathrm{C}_{14} \mathrm{H}_{13} \mathrm{O}_{4}$ & 314 & 53.47 \\
\hline 24. & 24.696 & 6-Azzaestera-1,3,5(10),6,8-pentaen-1,7-one,3-methoxy & $\mathrm{C}_{21} \mathrm{H}_{30} \mathrm{O}_{2}$ & 399 & 0.55 \\
\hline 25. & 26.221 & $9(10 \mathrm{H})$-Acridinone, 1-hydroxy-2,3-dimethoxy-10-methyl & & 285 & 1.84 \\
\hline 26. & 27.238 & Vitamin E & $\mathrm{C}_{19} \mathrm{H}_{15} \mathrm{NO}_{6}$ & 430 & 1.76 \\
\hline
\end{tabular}

\section{Antimicrobial susceptibility activity}

Rue exhibited a broad spectrum of antibacterial activity as represented in table 4 . Aqueous extract of Rue exhibited least antibacterial activity against the bacterial pathogens. Whereas, chloroform extract did not show any inhibitory effect against bacterial pathogens. This difference is attributed to the solubility of the active component in a different solvent [25]. The resistance observed by $B$. subtillis in methanolic extracts is more than ethanolic extract, while in the case of gram-negative bacteria $E$. coli was not sensitive to any of the extracts. While $C$. abicans showed resistance to most of the extracts used in this study except aqueous extract. A study has shown that increasing the dose of extracts from 100 $\mathrm{mg} / \mathrm{ml}$ to $200 \mathrm{mg} / \mathrm{ml}$, increased the susceptibility towards microorganism. However, the methanolic extract of Rue has greater antimicrobial activity as compared to other solvent extracts. Various photo components present in Rue extract including Fatty acid, saponins, tannins, flavonoids, alkaloids, terpenoids, glycosides, carotenoids, polyphenols and tannins are secondary metabolites which serve a protective mechanism against various microorganisms [26]. Flavonoids are hydroxylated phenolic compounds which are responsible for protection against microbial infection [27]. Saponin leads to leakage of proteins and some enzymes from the microbial cell and thus responsible for antimicrobial activity [28]. A previous study has shown that flavonoids and phenolic components present in the plant extract have potential antimicrobial activity [29]. Hence, we could hypothesize that the antimicrobial activity of Rue plant might be due 
to the presence of the above-mentioned phytoconstituents in the extract. Interestingly, some researchers reported the antibacterial activity of Rue plant and its cytotoxic activity which also supported the present study [30,31].

Table 4: Antibacterial activity of true with diameter of the zone of inhibition

\begin{tabular}{|c|c|c|c|c|c|c|c|c|}
\hline \multirow{3}{*}{$\begin{array}{l}\text { Test organisms } \\
\text { Dose }(\mathrm{mg} / \mathrm{ml}) \\
\end{array}$} & \multicolumn{8}{|c|}{ Zone of Inhibition in diameter(mm) inhibition zone include the diameter of disc (06 mm) } \\
\hline & \multicolumn{2}{|c|}{ Ethanolic extract } & \multicolumn{2}{|c|}{ Methanolic extract } & \multicolumn{2}{|c|}{ Chloroform extract } & \multicolumn{2}{|c|}{ Aqueous extract } \\
\hline & 100 & 200 & 100 & 200 & 100 & 200 & 100 & 200 \\
\hline B. subtilis & $16 \pm 0.35$ & $17 \pm 0.30$ & $18 \pm 0.17$ & $20 \pm 0.08$ & - & - & $07 \pm 0.22$ & $09 \pm 0.43$ \\
\hline E. coli & - & - & - & - & - & - & - & - \\
\hline P. vulgaris & $15 \pm 0.65$ & $16 \pm 0.25$ & $10 \pm 0.06$ & $11 \pm 0.18$ & - & - & $10 \pm 0.26$ & $11 \pm 0.18$ \\
\hline C. abicans & - & - & - & - & - & - & $07 \pm 0.22$ & $09 \pm 0.45$ \\
\hline C. tropicalis & - & - & - & - & - & - & - & - \\
\hline M. lutees & $14 \pm 0.20$ & $15 \pm 0.42$ & $12 \pm 0.28$ & $13 \pm 0.15$ & - & - & $07 \pm 0.04$ & $09 \pm 0.12$ \\
\hline
\end{tabular}

' \pm '-Standard Deviation, '-'-Absent

\section{CONCLUSION}

In conclusion, the phytochemical analysis revealed the presence of various secondary metabolites namely flavonoids, alkaloids, terpenoids, saponins and carotenoid in Rue extract and approximately 26 phytoconstituents as analyzed by GC-MS study. This study also revealed the antibacterial properties of Rue extract, which can be used as antimicrobial agents in drugs development of infectious disease. Further research on this plant can pave the way to newer innovation in herbal medicine.

\section{ACKNOWLEDGEMENT}

The authors acknowledge the support of central instrumentation facility from College of Health Sciences of Jimma University, Jimma, Ethiopia and Department of Zoology, University of Lucknow, Lucknow, India.

\section{CONFLICT OF INTERESTS}

No potential conflict of interest was reported by the authors

\section{REFERENCES}

1. Mahima, Rahal A, Deb R, Latheef SK, Abdul Samad H, Tiwari R, et al. Immunomodulatory and therapeutic potentials of herbal, traditional/indigenous and ethnoveterinary medicines. Pak J Biol Sci 2012;15:754-74.

2. Ekor M. The growing use of herbal medicines: issues relating to adverse reactions and challenges in monitoring safety. Front Pharmacol 2014;10:177.

3. Raghav SK, Gupta B, Agrawal C, Goswami K, Das HR. Antiinflammatory effect of Rue L. in murine macrophage cells. J Ethnopharmacol 2006;104:234-9.

4. Eldalawy R. Quantitative estimation of rutin in rue (Ruta graveolens L.) cultivated in Iraq with the evaluation of its antioxidant activity. Asian J Pharm Clin Res 2017;10:353-5.

5. Preethi KC, Nair CKK, Kuttan R. Clastogenic potential of Rue extract and a homeopathic preparation in mouse bone marrow cells. Asian Pac J Cancer Prev 2008;9:763-9.

6. Oliva A, Meepagala KM, Wedge DE, Harries D, Hale AL, Aliotta G, et al. Natural fungicides from Ruta graveolens L. leaves, including a new quinolone alkaloid. J Agric Food Chem 2003;51:890-6.

7. Kannan R, Babu UV. Identity and pharmacognosy of Ruta graveolens Linn. Anc Sci Life 2012;32:16-9.

8. Preethi K, Kuttan G, Kuttan R. Anti-tumour activity of rue extract. Asian Pac J Cancer Prev 2006; 7:439-43.

9. Cook NC, Samman S. Flavonoids-chemistry, metabolism, cardioprotective effects, and dietary sources. J Nutr Biochem 1996; 7:66-76.

10. Van Acker SA, Tromp MN, Haenen GR, Van der Vijgh WJ, Bast A. Flavonoids as scavengers of nitric oxide radicals. Biochem Biophys Res Commun 1995;214:755-9.

11. Réthy B, Zupkó I, Minorics R, Hohmann J, Ocsovszki I, Falkay G. Investigation of cytotoxic activity on human cancer cell lines of arborinine and furane acridones isolated from Ruta graveolens. Planta Med 2007;73:41-8.

12. Khan NH, Kamal MSA, Rhaman M. Antibacterial activity of Euphorbia thymifolia Linn. Indian J Med Res 1988;87:395-7.
13. Kaminskas A, Mažeikienè A. Biochemistry laboratory manual: colour reactions of protein (peptides) and amino acids. Vilnius University, Vilniusity; 2012.

14. Parekh J, Chanda SV. In vitro antimicrobial activity and phytochemical analysis of some Indian medicinal plants. Turk J Biol 2007;31:53-8.

15. Van-Burden TP, Robinson WC. Formation of complexes between protein and tannin acid. J Agric Food Chem 1981;1:77.

16. Edeoga HO, Okwu DE, Mbaebie BO. Phytochemical constituents of some Nigerian medicinal plants. Afr J Biotechnol 2005;4:685-8.

17. Roy P, Abdulsalam FI, Pandey DK, Bhattacharjee A, Eruvaram NR, Malik T. Evaluation of antioxidant, antibacterial, and antidiabetic potential of two traditional medicinal plants of India: Swertia cordata and Swertia chirayita. Pharmacogn Res 2015; 7:S57-62.

18. El Sayed K, Al-Said MS, El-Feraly FS, Ross SA. New quinoline alkaloids from Ruta chalepensis. J Nat Prod 2000;63:995-7.

19. Günaydin K, Savci S. Phytochemical studies on Ruta chalepensis (Lam.) Lamarck. Nat Prod Res 2005;19:203-10.

20. Koblovská R, Macková Z, Vítková M, Kokoska L, Klejdus B, Lapcík O. Isoflavones in the Rutaceae family: twenty selected representatives of the genera Citrus, Fortunella, Poncirus, Ruta and Severinia. Phytochem Anal 2008;19:64-70.

21. Gomathi D, Kalaiselvi M, Ravikumar G, Devaki K, Uma C. GC-MS analysis of bioactive compounds from the whole plant ethanolic extract of Evolvulus alsinoides (L.) L. J Food Sci Technol 2015;52:1212-7.

22. Mancuso G, Borgonovo G, Scaglioni L, Bassoli A. Phytochemicals from rue activate TAS2R bitter taste receptors and TRP channels involved in gustation and nociception. Molecules 2015;20:18907-22.

23. Sharma DK. Bioprospecting for drug research and functional foods for the prevention of diseases-role of flavonoids in drug development. J Sci Ind Res 2006;2:391-401.

24. Badoni H, Sharma P, Waheed SM, Singh S. Phytochemical analyses and evaluation of antioxidant, antibacterial and toxic properties of Emblica officinalis and Terminalia bellirica fruit extracts. Asian J Pharm Clin Res 2016;9:96-102.

25. Caunii A, Pribac G, Grozea I, Gaitin D, Samfira I. Design of optimal solvent for extraction of bio-active ingredients from six varieties of Medicago sativa. Chem Cent J 2012;6:123.

26. Sharma H, Garg M. A review of traditional use, phytoconstituents and biological activities of Himalayan yew, Taxus wallichiana. J Integr Med 2015;13:80-90.

27. Cowan MM. Plant products as antimicrobial agents. Clin Microbiol Rev 1999;12:564-82.

28. Avato P, Bucci R, Tava A, Vitali C, Rosato A, Bialy Z, et al. Antimicrobial activity of saponins from Medicago sp.: structure-activity relationship. Phytother Res 2006;20:454-7.

29. Mahmoudi S, Khali M, Benkhaled A, Benamirouche K, Baiti I. Phenolic and flavonoid contents, antioxidant and antimicrobial activities of leaf extracts from ten Algerian Ficus carica L. varieties. Asian Pac J Trop Biomed 2016;6:239-45. 
30. Chaftar N, Girardot M, Labanowski J, Ghrairi T, Hani Frère J, Imbert $\mathrm{C}$. Comparative evaluation of the antimicrobial activity of 19 essential oils. Adv Exp Med Biol 2016;901:1-15.

31. Ivanova A, Mikhova B, Najdenski H, Tsvetkova I, Kostova I. Antimicrobial and cytotoxic activity of Ruta graveolens. Fitoterapia 2005;76:344-7.

\section{How to cite this article}

- Henok Gulilat Azul work, Sahabjada, Asif Jafri, Md Arshad, Tabarak Malik. The phytochemical investigation, GC-MS profile and antimicrobial activity of a medicinal plant ruta graveolens L. from ethiopia. Int J Pharm Pharm Sci 2017;9(6):29-34. 